\title{
The Environmental Performance of Air Conditioning Systems in Heritage Buildings in Tropical Climates
}

\author{
Raha Binti Sulaiman ${ }^{1 *}$, Kamaruzzaman, S.N ${ }^{1}$, Rao, S. P ${ }^{1}$, Pitt, $\mathrm{M}^{2}$ \\ ${ }^{1}$ Faculty of Built Environment' University of Malaya, Kuala Lumpur, Malaysia \\ ${ }^{2}$ Bartlett Faculty of the Built Environment, University College London, London \\ *rahasulaiman@um.edu.my
}

\begin{abstract}
This paper examines the performance of retrofitting climate control systems focusing on air conditioning systems in refurbished old buildings in tropical climates. Data was gathered by means of investigation in the sequential steps of condition survey, space audit, ventilation systems, indoor/outdoor temperature reading and relative humidity (RH) measurement. The study raises several important issues relating to indoor environmental quality. Beyond the obvious aesthetical issues that are addressed here, the installation of air conditioning systems tends to create thermal instabilities and indoor environment imbalances in refurbished buildings. Furthermore, there is also a gap between the necessities of conserving the precious features of old buildings and the demand for better thermal comfort by the occupants. This study outlines the risks as well as making recommendations for future strategies.
\end{abstract}

Keywords: Climate control, indoor environment, heritage buildings, Malaysia

\section{Introduction}

Conservation of older buildings is an important way to safeguard a nation's cultural resources and to preserve cultural heritage. In tropical countries like Malaysia, the all year round regime of heavy rains accompanied by high temperatures contribute to the fluctuations of indoor climate which eventually affects the building fabric. This situation has damaging consequences for older buildings. Since the use of old buildings has usually changed from the time they were built; modern services cannot be installed without taking the risk of affecting their structural integrity. However, according to the Chartered Institution of Building Services Engineers (CIBSE, 2002), modern materials and techniques can be incompatible with traditional constructions. This point was illustrated in the case studies conducted by CIBSE, with the assistance of English Heritage, Historic Scotland and the National Trust. These case studies have also shown that when appropriate and efficient services alterations are implemented old buildings can be managed and maintained in a sustainable manner.

\section{Current Condition Air conditioning in old buildings within tropical climate}

Buildings in tropical climates are exposed to wide fluctuations of indoor as well as outdoor temperatures and hygrothermal levels. The indoor conditions are subject to the hygrothermal effects of water vapour condensation, moisture input from the fabric and air temperature fluctuations due to the contrasts between indoor and envelope temperatures. In Malaysia, for example, in 2005 the average daily outdoor air 
temperature was about $26.5^{\circ} \mathrm{C}$ whilst the outdoor RH varies from 75 to 85 percent (Nugrohu, 2007). Shin (2001) shows that during rainy season the air temperature varies from less than $5^{\circ} \mathrm{C}$ and increase to more than $15^{\circ} \mathrm{C}$ in the dry and sunshine season. The RH will then drop $5 \%$ for every $1^{\circ} \mathrm{C}$ increase. Daghigh (2008) however has reported that the daytime temperatures range of $29-34^{\circ} \mathrm{C}$ and relative humidity is of $70-90 \%$ throughout the year.

Figure 1 shows the 30-year average of dry bulb temperatures, RH and mean wind velocities for various months in Kuala Lumpur. Malaysia experiences high relative humidity, varying from $67 \%$ to $96 \%$ with an average value of around $80 \%$. The outdoor air temperature varies from $24 \mathrm{deg} \mathrm{C}$ to a maximum of $33 \mathrm{deg} \mathrm{C}$. There is no dominant wind direction.

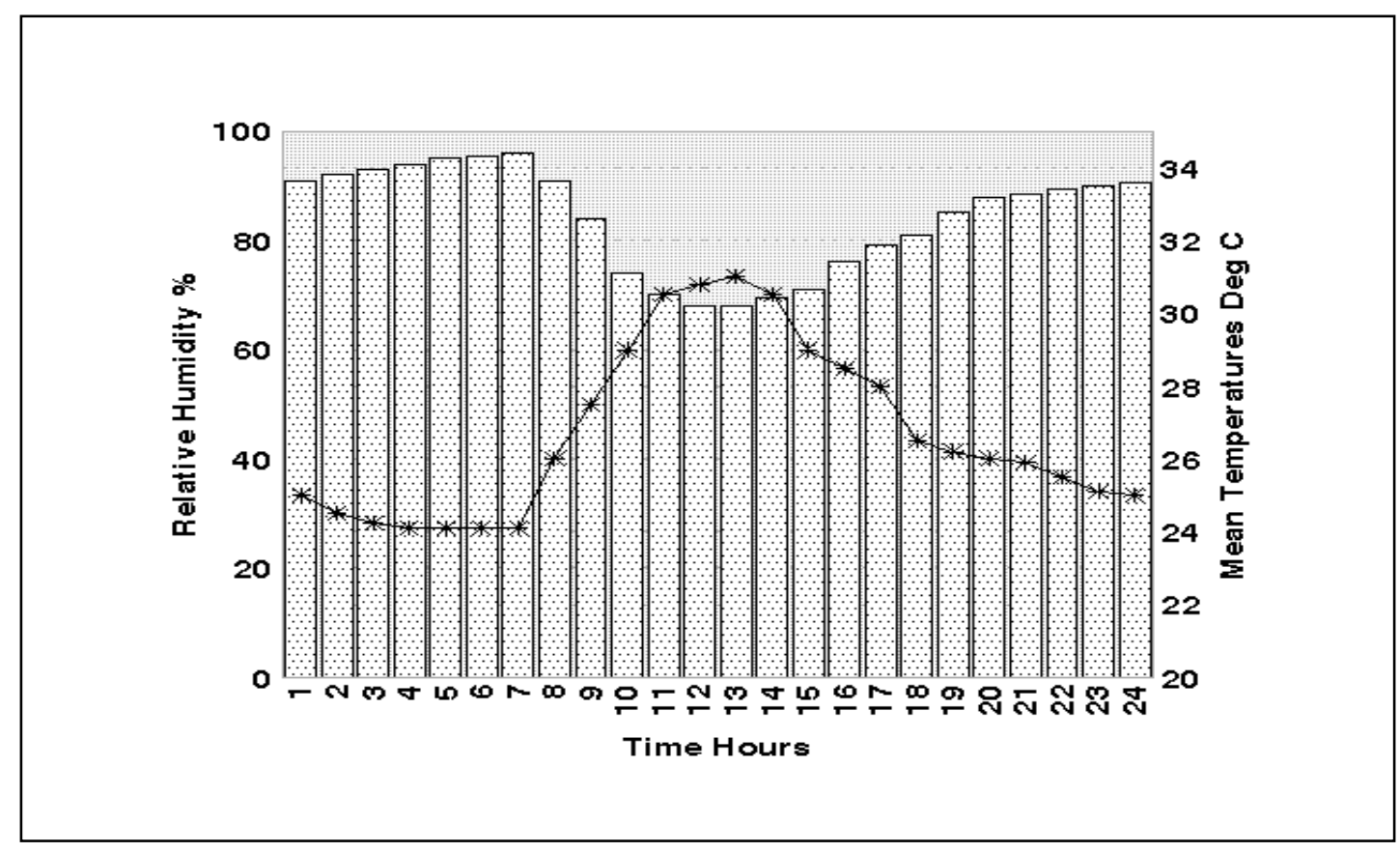

Figure 1: Hourly values of outdoor air temperatures and relative humidity in Kuala Lumpur, Malaysia. (Source: Woods, 2001)

Thus the thermal and hygrographic stress is always present, and of course, it affects the comfort level within all buildings and makes comfort adjustments more difficult in buildings using traditional materials, layouts and design. Moreover, the traditional materials in old buildings are now less capable of adapting to their change of usage to outdoor condition. In the short term, the risks due to active ventilation alteration are the risks of changing the indoor cooled environment. In the long term, problems will occur due to the frequencies of interaction between the buildings fabric and both outdoor and indoor condition. The issues here are of condensation, which relates to dampness, humidity, moisture movements and temperature.

Previous studies have shown that the fabric of older buildings may not withstand the systems due to the different parameters of indoor climate condition and the requirements of peoples' comfort conditions (Balocco, 2006). For Gysels (2004), the imbalanced system which produced rapid changes will affect to the microclimate of the buildings and further marks thermo-hygrometric gradients. Once the building is cooled, its indoor environment might be changed and this scenario is often intrusive to the old buildings' fabric (Maekawa, 2001). 
Under these circumstances, the building elements are affected due to the unsuitability of the new indoor environment to the properties of the building materials used.

Very few studies have been conducted on old buildings and air conditioning in tropical climate conditions. Ahmad (1996) has conducted research on air conditioning in old office buildings. However, none on his research covered the importance of having indoor environment and microclimate measurement to study the affect and effect of air conditioning to the buildings. Kamaruzzaman et al. (2009) only mention about the energy consumption and efficiencies of the air conditioning in refurbished historic buildings. Furthermore, Kamaruzzaman et al. (2010) also only look into the indoor environmental qualities in refurbished historic buildings in Malaysia. Meanwhile, Kayan (2006) specifically described the problems with poor installation of retrofitted air conditioning. None of these works address the issues in this paper. However, some evidence is offered through a dilapidation survey on several historical buildings in the Historical City of Malacca which was carried out in 2007 (Zawawi, 2007). Here it was found that the retrofitted air conditioning systems in the building had damaged the existing internal building elements.

Based on the studies conducted, there is clear evidence that the overall refurbishment works of installing air conditioning system in an old building presents risks to the existing building elements. However, only in hot and humid climate conditions do the problems with the installation of cooling system appear prevalent. In many other parts of the world, heating systems are used in old buildings to accommodate changes in their usage and demand (Schellen 2002, Limpens-Neilen, D., 2006). The different operation of HVAC systems contribute to different results. The heating cycle is clearly not required in tropical climates. Thus, in tropical climates the old buildings' structures and fabrics can be over exposed to cool indoor environments and moisture movements due to continuous exposure of low temperatures and associated humidity. This raises the question as to whether we should be prepared to sacrifice the conserved fabric and appearance just to accommodate current service standards. This paper addresses both the issues of conservation of old buildings and the refurbishment works, thus increasing the range of upgrading the services to modern standard especially the installation of retrofit air conditioning.

\section{Materials \& Methods}

\subsection{Audit and Data Acquisition}

A thorough site survey was conducted from June 2008 to August 2008 to investigate the indoor environmental performance of refurbished historic buildings. The investigation was carried out sequentially in consecutive steps of condition survey: (i) space audit (ii) ventilation system and (iii) indoor/outdoor temperature and RH measurement. Meetings with the with the maintenance officers/staff and local authorities was also taken place in order to collect as much information about the buildings studied.

\subsection{Space Audit}

Space audits were carried out initially before the condition survey proceeded to other steps. In this audit, sizes and usage of the space, building elements and materials used were recorded. These were done by 
observation, visual survey and measurement. Any changes and refurbishments works to the building and also to the spaces were investigated and recorded. Previous records and oral evident were used to validate and proved all findings.

\subsection{Ventilation system audit}

In this stage, means of ventilation systems used in each space were identified by visual observation. In general ventilation systems mainly fall into three main categories; either the space is fully natural ventilation, combination of natural and mechanical ventilation (mixed mode) or fully mechanical ventilation. The systems identified during the audit were recorded and the manufacturers' catalogues were then used as references to get their detail descriptions. The energy consumption for each system were calculated and compared to the national guideline.

\subsection{Temperature and RH measurement}

As the tools and equipments are limited, the measurements were recorded manually in every one hour. These were done in two sessions (to accommodate two different groups of building users); in the morning from 8 am until 12 noon and in the evening from $1 \mathrm{pm}$ until $4 \mathrm{pm}$. The digital Pyschrometer is used to measure the RH and the air temperature. By spot measuring devices, three readings were recorded for each time in order to reduce the variation. During the measurement, all the mechanical devices were on, all windows and doors were open and the spaces were occupied by the users. The readings were then calculated to get the mean temperature and mean RH.

\subsection{Description of Buildings}

The criteria for selection were that this selected old building has yet to be gazetted as historic building. Therefore, conservation and preservation guideline are not really implemented in any refurbishment works done in this building. Secondly, there was evidence that air conditioning systems were installed and used in this building. Thirdly, the 3 storeys building were made of $235 \mathrm{~mm}$ thick masonry walls where it is believed that this help the building to survive for a very long period of time. Final consideration was that the building did not present basic maintenance works.

Table 2: Building's description

\begin{tabular}{|l|l|}
\hline Building & Educational building \\
\hline Concept & Influenced by the Roman architectural style with a touch of Art Deco. \\
\hline Year built & 1907 \\
\hline Status & To be gazetted as Historic Building under National Heritage Act 2005 (Act 645) \\
\hline Location & Kuala Lumpur, Malaysia \\
\hline
\end{tabular}




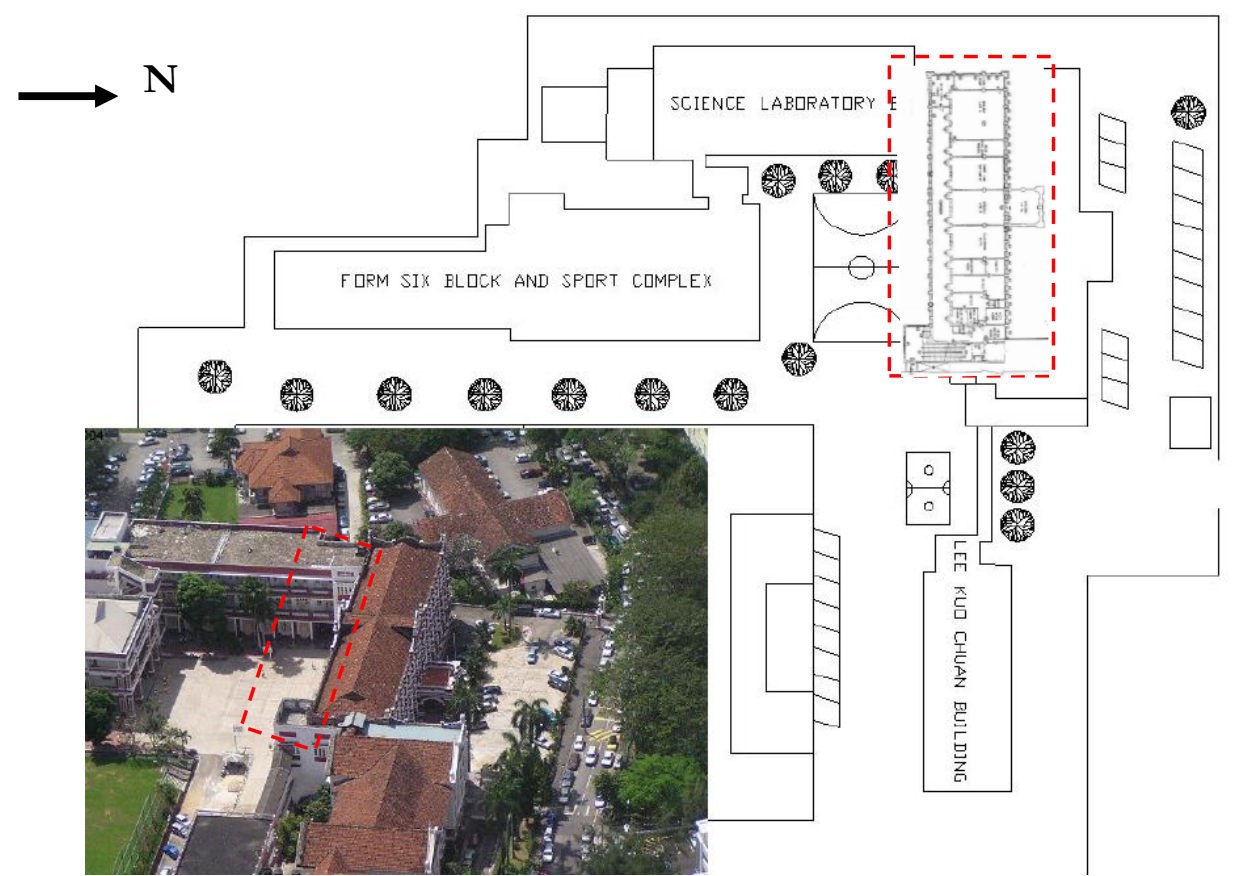

Figure 5: Aerial view of the overall institution and the building with red box was selected as the case study

\section{Results And Discussion}

\subsection{Refurbishment works and installation of air conditioning system}

The space audits shows that almost every space in the buildings has been refurbished (refer Table 2) and changed their existing environment. The most apparent changes were the installation of air conditioning systems in almost 58 percent of the spaces where at the end, lead to improper solutions; the existing windows were closed or covered by other inappropriate materials, changes in ceiling height and modification of the original spaces into new designated room.

Changes in ceiling height were meant to construct new suspended ceiling to house new lighting systems, electrical wiring and the air conditioning ducting. Floor finishes changed from original cement render to either homogenous tiles or vinyl floor tiles. Office area is a space with great changes where the original open plan has been divided into smaller rooms to accommodate assistance rooms, headmaster's room and administration office. By partitioning and reducing original size and height of the space, it will affect the existing air flow into and within the space. 
Table 2: Spaces with the detail descriptions on refurbishment works

\begin{tabular}{|c|c|c|c|c|}
\hline Space & Detail & $\begin{array}{c}\text { No. of } \\
\text { space/s }\end{array}$ & Size & Refurbishment description \\
\hline \multirow{3}{*}{ Laboratory } & $\begin{array}{l}\text { Smart Lab for } \\
\text { computers' lesson }\end{array}$ & 1 & $\begin{array}{c}6900 x \\
9850 x \\
2970\end{array}$ & $\begin{array}{l}\text { Existing windows have been fully closed } \\
\text { Installation of air conditioning system } \\
\text { Additional suspended ceiling } \\
\text { Additional homogenous floor tiles }\end{array}$ \\
\hline & \multirow{2}{*}{ Biology laboratory } & \multirow{2}{*}{2} & $\begin{array}{c}10500 \mathrm{x} \\
9850 \mathrm{x} \\
4800\end{array}$ & \multirow{2}{*}{$\begin{array}{l}\text { Existing windows are still in use. } \\
\text { Installation of new ceiling fan }\end{array}$} \\
\hline & & & $\begin{array}{c}7630 x \\
9850 x \\
4800 \\
\end{array}$ & \\
\hline $\begin{array}{l}\text { Meeting } \\
\text { room }\end{array}$ & Staff meeting room & 1 & $\begin{array}{c}7630 x \\
9850 x \\
4800\end{array}$ & $\begin{array}{l}\text { Existing windows have been fully closed } \\
\text { Installation of air conditioning system } \\
\text { Additional fully height timber frame plywood for } \\
\text { internal wall } \\
\text { Additional vinyl floor tiles }\end{array}$ \\
\hline \multirow[b]{2}{*}{ Classroom } & \multirow{2}{*}{$\begin{array}{l}\text { Students classroom } \\
* \text { each classroom is } \\
\text { designed to } \\
\text { accommodate students in } \\
\text { range of } 30-40 \text { students }\end{array}$} & \multirow[b]{2}{*}{14} & $\begin{array}{c}6900 x \\
9850 x \\
4800\end{array}$ & \multirow{2}{*}{$\begin{array}{l}\text { Existing windows are still in use } \\
\text { Installation of new ceiling fan } \\
\text { Additional fully height timber frame plywood for } \\
\text { internal wall } \\
\text { Additional vinyl floor tiles }\end{array}$} \\
\hline & & & $\begin{array}{c}6900 x \\
9850 x \\
3730\end{array}$ & \\
\hline $\begin{array}{l}\text { Garudamas } \\
\text { Room }\end{array}$ & $\begin{array}{l}\text { Editorial room for school } \\
\text { magazine }\end{array}$ & 1 & $\begin{array}{c}3480 x \\
6900 x \\
2970\end{array}$ & $\begin{array}{l}\text { Additional new room } \\
\text { Additional fully height gypsum partition for internal } \\
\text { wall } \\
\text { Additional suspended ceilings } \\
\text { Additional homogenous floor tiles } \\
\text { No windows at all } \\
\text { Installation of air conditioning system }\end{array}$ \\
\hline \multirow{4}{*}{ Office } & $\begin{array}{l}\text { Form } 3 \text { Academic } \\
\text { Advisor }\end{array}$ & 1 & $\begin{array}{c}3350 \mathrm{x} \\
9850 \mathrm{x} \\
4800 \\
\end{array}$ & \multirow{4}{*}{$\begin{array}{l}\text { Existing windows in some of the rooms have been fully } \\
\text { closed } \\
\text { Installation of air conditioning system and ceiling fan } \\
\text { Additional fully height gypsum partition for internal } \\
\text { wall } \\
\text { Additional suspended ceiling at majority of the area } \\
\text { Additional plaster ceiling for headmaster's room } \\
\text { Additional homogenous floor tiles in some area }\end{array}$} \\
\hline & $\begin{array}{l}\text { Assistance office } \\
* \quad \text { Assistance } 1 \\
* \quad \text { Assistance } 2 \\
* \quad \text { Assistance } 3 \\
* \quad \text { Assistance } 4\end{array}$ & 4 & $\begin{array}{c}3400 \mathrm{x} \\
3350 \mathrm{x} \\
30550 \\
3400 \mathrm{x} \\
2290 \mathrm{x} \\
2500 \\
3400 \mathrm{x} \\
2140 \mathrm{x} \\
2500 \\
6900 \mathrm{x} \\
3330 \mathrm{x} \\
4800 \\
\end{array}$ & \\
\hline & Headmaster room & 1 & $\begin{array}{c}2900 x \\
5430 x \\
3030 \\
\end{array}$ & \\
\hline & Administration & 2 & $\begin{array}{c}3350 \mathrm{x} \\
7230 \mathrm{x} \\
4800 \\
3530 \mathrm{x} \\
9850 \mathrm{x} \\
2340\end{array}$ & \\
\hline
\end{tabular}




\subsection{Means of ventilation systems}

Based on the original design, the building has energy saving physical features and devices such as the thick masonry walls that contribute to good thermal performance. The orientation of the building helps the building to receive minimum external heat gain into the building. In general, the main openings of the buildings are facing to the North-East/South-West and will minimize the amount of direct solar radiations to the building. By having operable windows and large balcony facing open court yard, these features help the building to receive the natural sources of required day lighting and natural ventilation (Figure 6). The heavy and thick masonry wall, which used so typically in old buildings exhibit characteristic that, improves their thermal performance. Based on Table 2, originally the building had high ceiling and give an advantage for natural ventilation. It is predicted that originally, this building was only rely on natural ventilation.

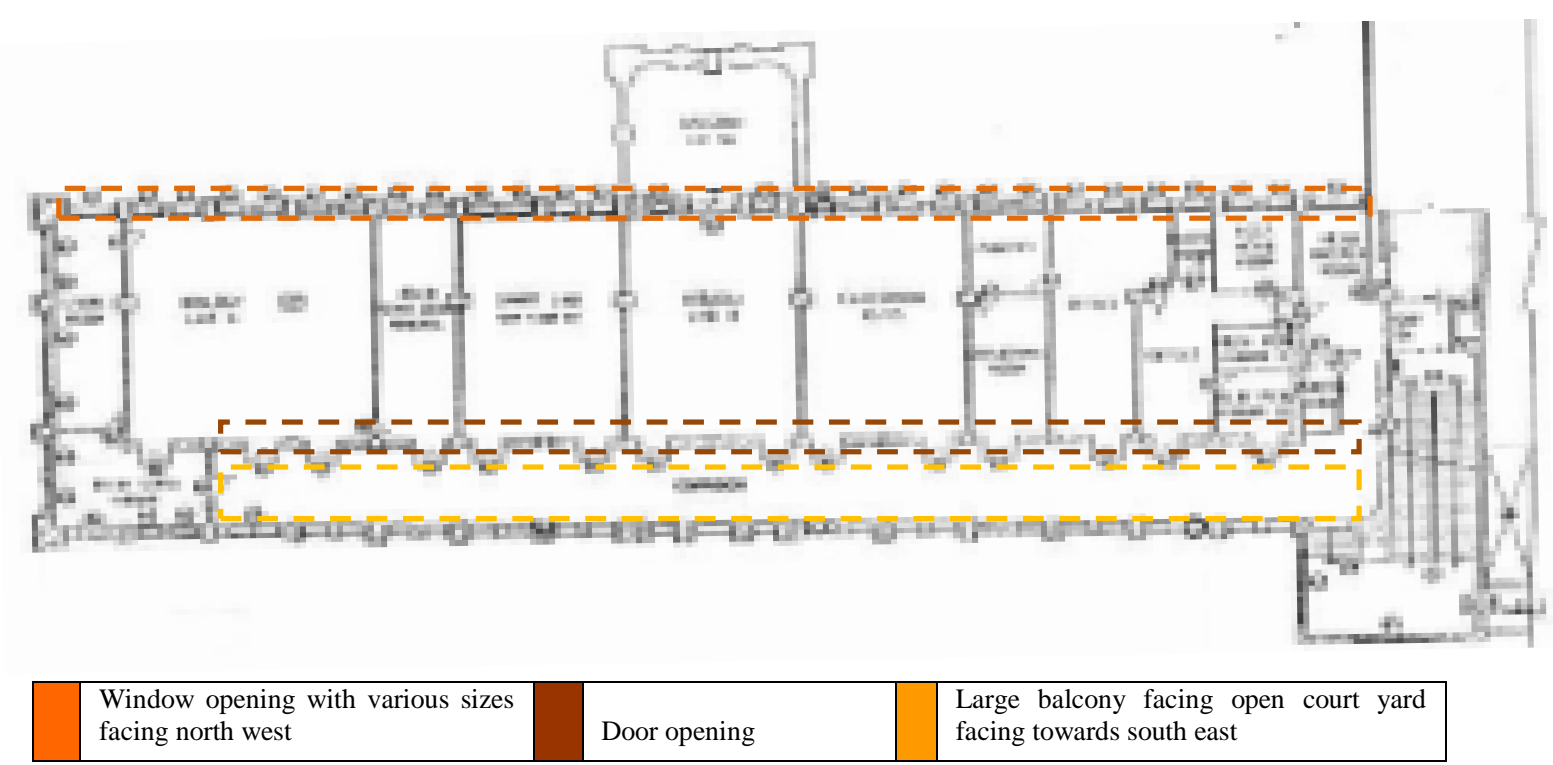

Figure 6: Typical floor plan of the building indicating openings to receive natural ventilation

Changes in ventilation systems used in the buildings and energy consumption were recorded as per Table 3. It shows that only classroom with less refurbishment works used ceiling fan while others were in great demand to use air conditioning systems as their means of ventilation.

The wrong systems, particularly in active ventilation systems, can be a threat to old buildings (Climate for Culture, 2009). In old buildings, especially those which are of interest to be gazetted as historic building, the ultimate aim is to making things last longer (Ashley-Smith, 1999) or sustainable as those is the natural assets not only for today but also for the use of future generation. The risk here is the consequence of a new process of the building fabric through a very long event (Brokerhef, 2006). There is a clear risk of a reduction in the overall value of the building. Even though the new National Heritage Act 2005 (Act 645) (Laws of Malaysia, 2006), has been implemented legislation for old buildings is still insufficient to protect them from being refurbished (Kamal, 2008). 
Table 3: Audit on ventilation system and energy consumption in each space

\begin{tabular}{|c|c|c|c|c|c|}
\hline \multirow[t]{2}{*}{ Space } & \multirow{2}{*}{$\begin{array}{c}\text { Means of } \\
\text { ventilation }\end{array}$} & \multirow{2}{*}{$\begin{array}{l}\text { No of air- } \\
\text { conditioners }\end{array}$} & \multirow{2}{*}{ No of fan } & \multicolumn{2}{|c|}{ Energy Consumption (KW/h) } \\
\hline & & & & Air-cond & Ceiling Fan \\
\hline & Air cond. & 2 & - & 5.892 & \\
\hline Laboratory & Ceiling fan & - & $\begin{array}{c}5 \text { and } 4 \text { for each } \\
\text { space }\end{array}$ & & 0.7 \\
\hline $\begin{array}{l}\text { Meeting } \\
\text { room }\end{array}$ & Air cond. & 2 & - & 4.338 & \\
\hline Classroom & Ceiling fan & - & 4 in each classroom & & 4.354 \\
\hline $\begin{array}{c}\text { Garudamas } \\
\text { Room }\end{array}$ & Air cond. & 1 & - & 2.169 & \\
\hline \multirow{3}{*}{ Office } & Air cond. & 6 & - & 9.906 & \\
\hline & Ceiling fan & - & $\begin{array}{c}1 \text { and } 2 \text { for each } \\
\text { space }\end{array}$ & & 0.233 \\
\hline & $\begin{array}{l}\text { Air cond. } \\
\text { and Ceiling } \\
\text { fan }\end{array}$ & 1 & 1 & 1.16 & 0.078 \\
\hline \multicolumn{4}{|c|}{ GRAND TOTAL OF ENERGY CONSUMPTION } & 23.465 & 5.365 \\
\hline
\end{tabular}

\subsection{Poor installation of an air conditioning system}

The installation of retrofit air conditioning in the buildings and risk-prediction upon refurbished activities are the problems which are of interest to be discussed other than affected façade of the buildings. In Fig. 7, the piping connected from the outdoor unit to the indoor unit is simply exposed and run through the bored hole of the preserved historic wall. Furthermore, the existing opening which was previously meant for natural ventilation has been modified in order to make the space fully enclosed. This definitely goes against the current guidelines as stipulated in the National Heritage Act (2005) as well as in other conservation guidelines where 1 the whole façade of old buildings need to be conserved and retained to maintain its authenticity and the significance of design value.
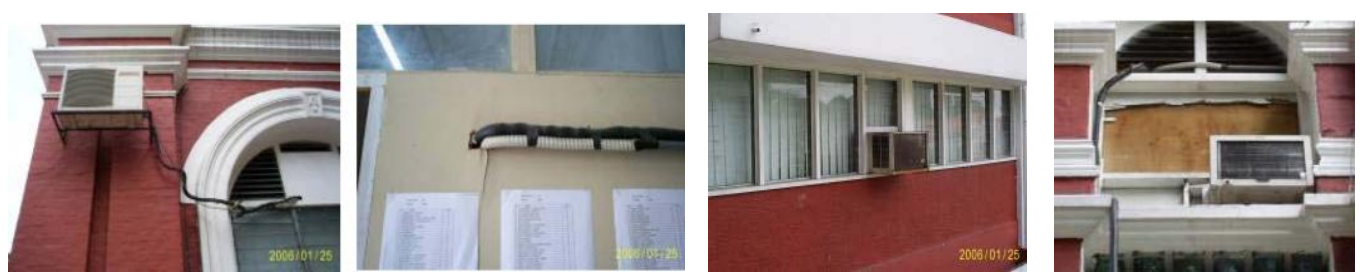

Figure 7: Poor planning and installation of outdoor air conditioning unit which affected the buildings' façade; (i) exposed of outdoor unit, (ii) poorly enclosed of existing window 


\subsection{Improper selection of air conditioning leading to higher cooling load and energy consumption}

Table 3 shows the energy consumption from each ventilation system. From the figures, the application of retrofit air conditioning in the building contributes at $81.39 \%$ of the total power consumption from the active ventilation systems. Old buildings were built without knowing future demand on highly sophisticated plant. Once these buildings are 'trapped' with current scenario of global warming, the demand from the occupier and the user to obtain comfort indoor environment is much more important than to sustain the existing building stock.

Furthermore, Table 3 also shows that there are 10 spaces in the main block which are installed with retrofit air conditioning but, after comparing the requirements and guidelines for an efficient air conditioning system, 7 of them are more demanding than the required capacity (Table 4). An oversized air conditioner means that the supplied cooling load is far exceeding than the required loading. This will lead to several problems such as higher energy consumption, higher maintenance needs and the higher chances of short term and long term risks to the physical indoor environment.

Table 4: Number of retrofit air conditioning systems which are over supplied

\begin{tabular}{|c|c|c|c|c|}
\hline \multirow[t]{2}{*}{ Space } & \multicolumn{2}{|c|}{$\begin{array}{c}\text { Retrofitted air } \\
\text { conditioning }\end{array}$} & \multirow{2}{*}{$\begin{array}{c}\text { Required size } \\
(\mathbf{h p})^{*}\end{array}$} & \multirow[t]{2}{*}{ Status } \\
\hline & Unit & Size (hp) & & \\
\hline Smart Lab & 2 & 3 & 4 & \\
\hline Garudamas room & 1 & 2 & 1.5 & \\
\hline Office admin & 2 & $3 \& 1.5$ & 2 & \\
\hline Assistance room 1 & 1 & 1.5 & 0.75 & Over demand \\
\hline Assistance room 2 & 1 & 1.5 & 0.75 & \\
\hline Assistance room 3 & 1 & 1.5 & 0.75 & \\
\hline Headmaster room & 1 & 1.5 & 1 & \\
\hline
\end{tabular}

\subsection{Temperature and RH measurement}

\subsubsection{Temperature and RH as agent of deterioration}

The given data in Table 5 was observed during the normal operation and activities of the spaces (the ventilation systems were on and the spaces were in use). Different readings would be anticipated outside working hours. Furthermore, the selected case study is to accommodate two different groups of building users in two sessions every day and throughout the years except for Saturday and Sunday. All these situations will make the tendency to be for the air conditioning to be switched on and off several times a day. This will cause sudden abrupt variations in temperature and RH. Several repetitions of the cycles in the long run will not only give risk to the building but also to the microclimate of the area. Any incorrect levels of them play the important risks that need to be encountered (Michalski, S 2009). The indoor microclimate of the space in this building should be 
controlled with the consideration on preservation strategies for the materials or otherwise there will be a risk of deterioration. Improper management using inappropriate environmental parameters such as overly generous $\mathrm{RH}$ and temperature upper and lower limits can be the agents of deterioration to old objects including the building itself. Decay is a long and continuous process and every temperature and RH change causes internal tensions with the different responses of the different materials surfaces and internal layers.

\subsubsection{Temperature and RH in thermal comfort demand}

It was found that whether the spaces were equipped with air conditioning or only a ceiling fan, the temperature and $\mathrm{RH}$ of all spaces in buildings fall in the acceptable range of comfort level. Only a slight discomfort occurred in the spaces which used ceiling fan or mixed mode ventilation system during the afternoon at $2.5-8^{\circ} \mathrm{C}$ increased. These spaces were not installed with the retrofitted air conditioning because of the difference in the building users group. These spaces were occupied by students. Smart lab is a computer laboratory which expected to give higher internal heat gain from the electrical equipments and therefore, having air conditioning can be a short cut solution in terms of thermal comfort demand but not in efficient energy consumption. Meanwhile, in the office area, where the people inside were mainly carrying out only sedentary activities with 1.5 metabolic rate (Daghigh R, 2009), the over supplied cooling load air conditioning systems were not a good option.

\subsubsection{Temperature and RH in energy consumption}

Setting the room temperature lower than the lowest average temperature of acceptability will cause air conditioning systems to use more electricity. $1^{\circ} \mathrm{C}$ temperature difference represents important difference in energy consumption estimated at $7-10$ percent of the air conditioning electricity bill (Yamtraipat, N. 2005). The proposed $26^{\circ} \mathrm{C}$ is therefore a good compromise in these spaces (Wan J W 2009, Yamtraipat, N. 2005) compared to $24^{\circ} \mathrm{C}$ as the higher temperature of the air conditioning can reduce the energy consumption of the system. However, due to the over supplied of air conditioning cooling load as discussed in previous section, this will lead to higher energy consumption in Smart Lab and in the office. 
Table 5: Daily mean internal/ external of ${ }^{\circ} \mathrm{C} / \mathrm{RH}$ in the morning and afternoon

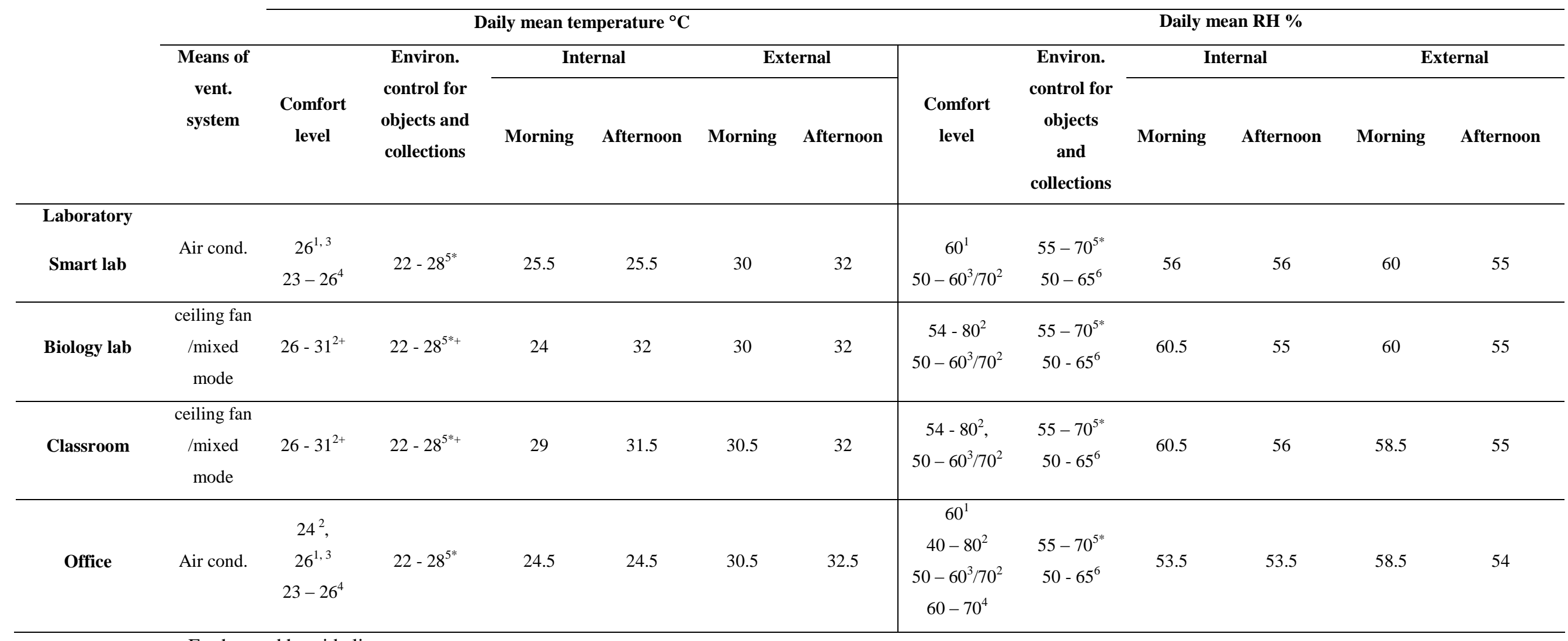

$+\quad 27.2$ at $0.2 \mathrm{~m} / \mathrm{s}, \quad 28.3$ at $0.5 \mathrm{~m} / \mathrm{s}, \quad 30.3$ at $1.0 \mathrm{~m} / \mathrm{s}, \quad 31.2$ at $1.5 \mathrm{~m} / \mathrm{s}$

Source: ${ }^{1}$ Wan J W 2009, ${ }^{2}$ Daghigh R 2009, ${ }^{3}$ Yamtraipat, N 2005, ${ }^{4}$ Malaysian Standard 2001, ${ }^{5}$ Heritage Collections Council $2002,{ }^{6}$ The National Trust 2005 


\section{Conclusion}

In reality, no active system is free from risk (Camuffo, 2002) whether it is used in an old or a new building. Rigorous multidisciplinary cooperation and approaches are needed between the various professions (Cassar, 2004, Camuffo, 2002) not only for surveyors, but also together with conservationists, architects, engineers and scientists who are experts in science of conservation, microclimate and the system (Camuffo, 2002).

With the scenarios of heavy rainfall and high solar radiation intensities during the day, with peak values of about $1000 \mathrm{~W} / \mathrm{m}$ during the day on most of the days in the year, with very little diurnal variations all year round, the buildings in Malaysia tend to weather rapidly. These buildings are heavily exposed to the problems of short and long term environmental pressure. The awareness of building conservation practice in Malaysia can be considered as improving, a better perspective on performance monitoring, condition surveys and maintenance management for old buildings needs to be developed. The current activities especially in the maintenance approach of old buildings in Malaysia are basically still relying on conventional methods where manual, log book and written documentation will be the fundamental references together with proper quenquennial inspections at some appropriate interval period (Sahb, M 2007). Therefore, Malaysia cannot rely and depend only on these methods in order to prolong the life of the existing building stock. As research on old buildings requires the integration of comprehensive knowledge, a robust synergistic approach to the complex problem needs to be explored.

We can learn from successful European research concerning sustainable old and historic buildings and cultural collection such as Noah's Ark, Engineering Historic Future, Climate Change and the Historic Environment. Malaysian conservation best practice must be shifted into a new paradigm in which knowledge generated from practice and research may be used to introduce new ways to improve and replace existing conservation measures.

\section{References}

Ahmad A. G. (1996), A study of the Air Conditioning system in old office buildings in George Town and Alor Setar (in Malay), Penang, University Science Malaysia

Ashley-Smith Jonathan (1999), Risk Assessment for Object Conservation, United Kingdom: ButterworthHeinemann

Balocco C. (2006), Thermal and Velocity Field Analysis Inside an Historical Building - The Hall of Two Hundred Case Study, Proceedings of the COMSOL Users Conference, Milano

Camuffo, D, Bernadi A, Sturano G, Valentino A (2002), The microclimate inside the Pollaiolo and Botticelli rooms in the Uffizi Gallery, Florence, Journal of Cultural Heritage, 3, 155 - 161

Cassar, M. and Taylor, J. (2004), A cross-disciplinary approach to the use of archives as evidence of past indoor environments in historic, Journal of Society of Archivists, 25, No 2

CIBSE (2002), Guide to Building Services for Historic Building, London: The Chartered Institution of Building Engineers. 
Climate for Culture, Damage risk assessment, macroeconomic impact and mitigation strategies for sustainable preservation of cultural heritage in the times of climate change, FP7-ENV-2008-1,

Daghigh R, Adam N. M., Sopian K Sahari B. B (2009), Thermal comfort of an air-conditioned office through different windows-door opening arrangement, Building Services Engineering Research and Technology, 30 (1), 49 - 63,

Gysels K. et al (2004), Indoor environment and conservation in the Royal Museum of Fine Arts, Antwerp, Belgium, Journal of Cultural Heritage, 5 (2), 221-230.

Heritage Collections Council (2002), Guidelines for environmental control in cultural institutions, Australia: Commonwealth of Australia

Hui S. C. M (undated), Sustainable Management of Building Services System for Historic Building, Hong Kong: The University of Hong Kong

Kamal K.S, Ahmad A.G, Wahab, L (2008), Pilot Survey on the Conservation of Historical Buildings in Malaysia, Proceeding of the 2nd International Conference, Built Environment in Developing Countries, 3rd - 4th December 2008, University Science of Malaysia.

Kamaruzzaman, S.N., Azlan Shah Ali, Zulkiflee Abdul-Samad and Emma M. A. Zawawi (2009), Energy performance of electrical support facilities: The case of adaptive re-used historical buildings in Malaysia, International Journal of Physical Sciences, Vol. 4 (12), 752-757

Kamaruzzaman, S. N., Emma Zawawi, M. A., Michael Pitt and Zuraidah Mohd Don (2010), Occupant feedback on indoor environmental quality in refurbished historic buildings, International Journal of Physical Sciences, 5 (3), 192 - 199

Kayan, B (2006), Building maintenance in old buildings conservation approach: an overview of related problems, Journal of Design and Built Environment, 2, 41 - 56,

Kunzel H. M., Zirkelbach, D., Sedlbauer, K. (2003), Predicting Indoor Temperature and Humidity Conditions Including Hygrothermal Interactions with the Building Envelope, Proceedings of 1st International Conference on Sustainable Energy and Green Architecture, Building Scientific Research Centre (BSRC), King Mongkut's University Thonburi, Bangkok 8-10 Oct. 2003.

Limpsen-Neilen, D, Bench Heating in Monumental Churches Thermal Performance of a Prototype, $\mathrm{PhD}$ thesis, Netherland: Eindhoven University of Technology

Maekawa, S., Toledo F. (2001), Sustainable Climate Control for Historic Buildings in Hot and Humid Regions, PLEA 2001, Proceeding of the 18th Conference on Passive and Low Energy Architecture, Florianopolis, Brazil, 7-9 November 2001, Paper code PL01-386

Laws of Malaysia (2006), National Heritage Act (2005) Act 645, Malaysia: The Commissioner of Law Revision Michalski S (2009), Incorrect relative Humidity, Retrieved April, 2010 from Canadian Conservation Institute, Canadian Heritage website: http://www.cci-icc.gc.ca/crc/articles/mcpm/chap10-eng.aspx

Nugrohu A M, Ahmad M. H, Ossen D. R. (2007), A Preliminary Study of Thermal Comfort in Malaysia's Single Storey Terraced Houses, Journal of Asian Architecture and Building Engineering, 6, 182

Sahb, M., Kamal K. S, Zaidi, M. A, Wahab, L (2007), Maintenance approach of historic buildings in Malaysian context, Building Engineer International News, Association of Building Engineers, Northampton. Spring, 8-11. 
Schellen H.L, Heating Monumental Churches: Indoor Climate and Preservation of Cultural Heritage, $\mathrm{PhD}$ Dissertation, The Netherland: Technische Universiteit Eindhoven, the Netherland

The National Trust (2005), Conservation Directorate, Guidance Note No 6/2, May 2005

Wan J.W. , Yang K, Zhang W J, Zhang J L (2009), A new method of determination of indoor temperature and relative humidity with consideration of human thermal comfort, Building and Environment, 44, 411417

Woods, P.C. Mohamed Ali and Lukman (2001), Design Model Day Climate in Malaysia, Seminar of the Department of Architecture, Malaysia: University of Malaya

Yamtraipat N., Khedari, J., Hirunlabh, J. (2005), Thermal comfort standards for air-conditioned buildings in hot and humid Thailand considering additional factors of acclimization and education level. Solar Energy, 78 (4), 504-517

Zawawi, R, Baharum M. R, Sulaiman R, Dilapidation Survey on Selected Historical Buildings within Malacca Historical City, Report and tender document for Heritage Department, Ministry of Arts, Culture and Heritage, Malaysia, 2007. 